九州大学学術情報リポジトリ

Kyushu University Institutional Repository

\title{
Basic Avoidance of Food Competition among Ruminants, Non-Ruminants and Humans - A Simple Analytic Description -
}

Shimojo, Masataka

Laboratory of Animal Feed Science, Faculty of Agriculture, Kyushu University

Bungo, Takashi

Shikoku National Agricultural Experiment Station

Imura, Yoshimi

Laboratory of Animal Feed Science, Faculty of Agriculture, Kyushu University

Tobisa, Manabu

Laboratory of Animal Feed Science, Faculty of Agriculture, Kyushu University

他

https://doi.org/10.5109/24331

出版情報 : 九州大学大学院農学研究院紀要. 44 (3/4)，pp.293-297，2000-02. Kyushu University バージョン：

権利関係 : 


\title{
Basic Avoidance of Food Competition among Ruminants, Non-Ruminants and Humans - A Simple Analytic Description -
}

\author{
Masataka Shimojo, Takashi Bungo*, Yoshimi Imura, Manabu Tobisa, \\ Mitsuhiro Furuse, Yasuhisa Masuda, Yasukatsu Yano, Yutaka Nakano**, \\ Tao Shao, Muhammad Yunus and Ichiro Goto***
}

Laboralory of Animal Feed Science, Faculty of Agriculture, Kyushu University, Fukuoka 812-8581, Japan

(Received October 29, 1999 and accepted November 5, 1999.9)

\begin{abstract}
The present study suggested a simple analytic description of the basic avoidance of food competition among ruminants, non-ruminants and humans when it was based on the production of forages, grain crops for human consumption and extra grain crops as animal feeds. The results obtained were as follows. (1) Humans depended basically on the plant production for the raw materials of foods, where harvest index of total grain crops, the proportion of grain crop production for human consumption to lotal grain crop production and the production ratio between forages and total grain crops were essential factors. (2) Forages and straws from both grain crops and extra grain crops were used as ruminant feets. (3) Extra grains were used as a non-ruminant feed. (4) Grains and animal protein from both ruminants and non-ruminants were used for human consumption. The results (1), (2), (3) and (4) supported the human life.
\end{abstract}

\section{INTRODUCTION}

Modern systems of farm animal production in developed countries require large amount of grains for the feeding of animals, because there is a considerable increase in the consumption of animal protein by many people (Blakely and Bade, 1994). In contrast, in developing countries there is a serious malnutrition in many people, especially in children, because of the terribly insufficient supply of foods (Cunha, 1990). This inequality is considered very difficult to solve due to the effects of many complicated factors, but the avoiding of food competition between humans and farm animals may make a small contribution to the supplying of enough amount of food to each person on the carth. In the preceding paper (Shimojo et al., 2000) we suggested a simple analytic description of the basic dividing of foods between ruminants and humans, where non-ruminants were not included. Non-ruminant farm animals; which are represented mainly by poultry and swine, also make a large contribution to human welfare (McDonald et al., 1995). The foed-conversion efficiency of non-ruminants fed grains is higher than that of ruminants fed forages (Preston and Leng, 1987), but the grain eating by non-ruminants may cause the food competition with humans unless there is an extra production of grain crops.

\footnotetext{
* Shikoku National Agricultural Experiment Station, Kagawa 765-8508

** Kyushı University Farm, Fikuoka 811-2307

*** Lriversity of the Air, Fukuoka Study Center, Fukuoka 812-0016
} 
The present study was designed, using the hypothetic equation reported by Shimojo et al. $(1998,2000)$, to suggest a simplc analytic description of the basic avoidance of food competition among ruminants, non-ruminants and humans when based on the production of forages, grain crops for human consumption and extra grain crops as animal feeds.

\section{ANALYSES OF BASIC AVOIDANCE OF FOOD COMPETITION}

\section{Procedures common to analyses}

There are three procedures (A), (B) and (C) common to analyses in the present study.

(A) The following hypothetic equation [H] suggested by Shimojo et al. (1998), which shows a stretch of $W$ as follows, is used. Thus,

$\mathrm{H}=\left(\frac{1}{\alpha} \cdot \frac{d \beta}{d t}\right) \cdot\left(\frac{\alpha}{\gamma}\right) \cdot\left(\frac{d W}{d \beta}\right)$,

where $W=$ weight of something, $t=$ time, $\alpha, \beta$ and $\gamma$ are parameters.

(B) The following items are taken up for the insertion into equation (1) in various analyses. (i) $W_{A}=$ farm animal body weight. (ii) $W_{R}=$ ruminant body weight. (iii) $W_{\text {Ni }}=$ non-ruminant body weight. (iv) $W_{i l}=$ human body weight. (v) $F[F$ is regarded as not only the harvested forage weight but also the cumulative forage intake by ruminants on condition that there is a complete consumption]. (vi) $G+S[G+S$, where $G$ is the grain weight for human consumption and $S$ is the straw weight as a ruminant feed, is regarder as the cumulative grain and straw intake as well as the harvested grain crop weight on condition that there is a complete consumption]. (vii) $g+s[g+s$, which shows the extra grain crop weight ( $g=$ grain weight, $s=$ straw weight), is introduced as animal feeds. The harvested weight and the cumulative intake are the same on condition that there is a complete consumption].

(C) Equation (1) is used in the form of differential equation basically, but in some cases $d W / d \beta$ is allowed to be regarded as $W / \beta$ when $W$ and $\beta$ show plant factors, because they are each given the cumulative value over the period of growth.

\section{Food competition avoidance between farm animais and humans}

In this section ruminants and non-ruminants are grouped together into farm animals. In equation (1) $\alpha=W_{i}, \beta=(G+S)+(g+s)+F$ and $\gamma=W=W_{H}$, then, $\mathrm{H}$ for the food competition avoidance between farm animals and humans $\left[\mathrm{H}_{A i}\right]$ is described as follows:

$\mathrm{H}_{\mathrm{AH}}=\left\{\frac{1}{W_{A}} \cdot \frac{d((G+S)+(g+s)+F)}{d t}\right\} \cdot\left(\frac{W_{A}}{W_{H}}\right) \cdot\left(\frac{d W_{H}}{d((G+S)+(g+s)+F)}\right)$.

The form of equation (2) is changed to get the following two equations (3) and (4). Thus;

$$
\begin{aligned}
\mathrm{H}_{\mathrm{AH}} & =\left\{\frac{1}{W_{A}} \cdot\left(\frac{d G}{d t}+\frac{d(S+g+s+F)}{d t}\right)\right\} \cdot\left(\frac{W_{A}}{W_{I I}}\right) \cdot\left\{\frac{d W_{H}}{d(G+S+g+s+F)}\right\} \\
& =\left\{\frac{d W_{H}}{d(G+S+g+S+F)}\right\} \cdot\left\{\left(\frac{1}{W_{A}} \cdot \frac{d G}{d t}\right) \cdot\left(\frac{W_{A}}{W_{I I}}\right)+\left(\frac{1}{W_{A}} \cdot \frac{d(S+g+s+F)}{d t}\right) \cdot\left(\frac{W_{A}}{W_{H}}\right)\right\}
\end{aligned}
$$




$$
\begin{aligned}
& =\left\{\frac{d W_{H}}{d(G+S+g+s+F)}\right\} \cdot\left\{\left(\frac{1}{W_{I S}} \cdot \frac{d G}{d t}\right)+\left(\frac{1}{W_{A}} \cdot \frac{d(S+g+s+F)}{d t}\right) \cdot\left(\frac{W_{A}}{W_{H}}\right)\right\} . \\
\mathrm{H}_{\mathrm{AH}} & =\left\{\frac{1}{W_{A}} \cdot \frac{d\left(G+S+g+s+F^{*}\right)}{d t}\right\} \cdot\left(\begin{array}{l}
W_{A} \\
W_{H}
\end{array}\right) \cdot\left\{\frac{d W_{H}}{d(G+S+g+s+F)}\right\} \\
& =\frac{1}{W_{H}} \cdot \frac{d W_{H}}{d t} .
\end{aligned}
$$

Four terms in equation (3) are explained as follows. (i) $d W_{\mu \prime} / d(G+S+g+s+F)$ is regarded as the ratio of $W_{13}$ changes to $G+S+g+s+F$ [W $W_{1:}-$ GSgsF ratio]. $W_{13}-$ GSgsF ratio is not the efficiency of $G+S+g+s+F$ for $W_{i l}$ changes, because $g$ is not used as a human food and $S+s+F$ is unavailable for direct human consumption. (ii) $\left(1 / W_{H}\right) \cdot(d G / d t)$ shows the grain ingestion rate per unit $W_{l i}\left[\mathrm{GIRW}_{l}\right]$. (iii) $\left(1 / W_{A}\right) \cdot(d(S+g+s+F) / d t)$ shows the straw, extra grain and forage ingestion rate per unit $W_{A}\left[\operatorname{SgsFIRW} W_{A}\right.$. (iv) $W_{A} / W_{i l}$ is regarded as the farm animal body mass supplied for human consumption [ABMHC]. The term in equation (4), $\left(1 / W_{H}\right) \cdot\left(d W_{t i} / d t\right)$, shows the relative growth rate of $W_{H}\left[\mathrm{RGRW} W_{H}\right]$.

Equations (3) and (4) show that humans depend basically on the plant production $\left[d W_{H} / d(G+S+g+s+F)\right.$, or $\left(W_{I i}\right.$ changes $\left.) /\left(G+S+g+s+F^{r}\right)\right]$ for the raw materiajs of foods, where humans consume grain crops $\left[\left(1 / W_{H}\right) \cdot(d G / d t)\right]$ and animal protein from farm animals $\left[W_{A} / W_{H I}\right]$ eating straws from grain crops for human consumption, extra grain crops and forages $\left[\left(1 / W_{A}\right) \cdot(d(S+g+s+F) / d t)\right]$ to support the human life $\left[\left(1 / W_{h i}\right)\right.$. $\left.\left(d W_{H} / d t\right)\right]$. This agricultural system is considered reasonable, because it avoids the food competition between farm animals and humans.

\section{Food competition avoidance among ruminants, non-ruminants and humans}

In this section farm animals $\left[W_{A}\right]$ are divided into ruminants $\left[W_{k}\right]$ and non-ruminants $\left[W_{N R}\right]$ wher animal feeds are divided into fibrous feeds and extra grains. In equation (1) $\alpha$ $=W_{A}, \beta=(G+S)+(g+s), \gamma=W_{t l}$ and $W=F$, then, $\mathrm{H}$ for the food competition avoidance among ruminants, non-ruminants and humans $\left[\mathrm{H}_{\mathrm{RNRH}}\right]$ is described as follows:

$\mathrm{H}_{\mathrm{RNBII}}=\left\{\frac{1}{W_{A}} \cdot \frac{d((G+S)+(g+s))}{d t}\right\} \cdot\left(\frac{W_{A}}{W_{H}}\right) \cdot\left\{\frac{d F}{d((G+S)+(g+s))}\right\}$.

The form of equation (5) is changed as follows:

$$
\begin{aligned}
\mathrm{H}_{\mathrm{RNRH}} & =\left\{\frac{1}{W_{A}} \cdot\left(\frac{d G}{d t}+\frac{d g}{d t}+\frac{d(S+s)}{d t}\right)\right\} \cdot\left(\frac{W_{A}}{W_{H}}\right) \cdot\left\{\frac{d F}{d(G+S+g+s)}\right\} \\
& =\left(\frac{1}{W_{H}} \cdot \frac{d G}{d t}\right) \cdot\left\{\frac{d F}{d(G+S+g+s)}\right\}+\left(\frac{1}{W_{A}} \cdot \frac{d g}{d t}\right) \cdot\left(\frac{W_{A}}{W_{H}}\right) \cdot\left\{\frac{d F}{d(G+S+g+s)}\right\} \\
& +\left(\frac{1}{W_{A}} \cdot \frac{d(S+s)}{d t}\right) \cdot\left(\frac{W_{A}}{W_{I I}}\right) \cdot\left\{\frac{d F^{\prime}}{d(G+S+g+s)}\right\} .
\end{aligned}
$$

In equation (6) composed of 8 terms, $W_{A}$ in the $3 \mathrm{rd}$ and 4 th terms is replaced by $W_{N R}$, and $W_{A}$ in the 6 th and 7 th terms is replaced by $W_{k}$, respectively. These replacements give the following equations (7), (8) and (9). Thus, 


$$
\begin{aligned}
\mathrm{H}_{\mathrm{RNRH}}= & \left(\frac{1}{W_{I I}} \cdot \frac{d G}{d t}\right) \cdot\left\{\frac{d F}{d(G+S+g+s)}\right\}+\left(\frac{1}{W_{N R}} \cdot \frac{d g}{d t}\right) \cdot\left(\frac{W_{N R}}{W_{H}}\right) \cdot\left\{\frac{d F}{d(G+S+g+s)}\right\} \\
& +\left(\frac{1}{W_{R}} \cdot \frac{d(S+s)}{d t}\right) \cdot\left(\frac{W_{R}}{W_{H}}\right) \cdot\left\{\frac{d F}{d(G+S+g+s)}\right\} \\
= & \left\{\frac{1}{W_{H}} \cdot \frac{d G}{d t}+\left(\frac{1}{W_{N R}} \cdot \frac{d g}{d t}\right) \cdot\left(\frac{W_{N R}}{W_{H}}\right)\right\} \cdot\left\{\frac{d F}{d(G+S+g+s)}\right\} \\
& +\left(\frac{1}{W_{R}} \cdot \frac{d F}{d t}\right) \cdot\left(\frac{W_{R}}{W_{I I}}\right) \cdot\left\{\frac{d(S+s)}{d(G+S+g+s)}\right), \\
= & \left\{\begin{array}{c}
1 \\
W_{I I}
\end{array} \frac{d G}{d t}+\left(\frac{1}{W_{N R}} \cdot \frac{d g}{d t}\right) \cdot\left(\frac{W_{N R}}{W_{H}}\right)\right\} \cdot\left\{\frac{d}{d(G+S+g+s)}\right\} \\
& +\left(\frac{1}{W_{R}} \cdot \frac{d F}{d t}\right) \cdot\left(\frac{W_{R}}{W_{H}}\right) \cdot\left\{1-\frac{d(G+g)}{d(G+S+g+s)}\right\} \cdot
\end{aligned}
$$

Six different terms in equation (7) are explained as follows. (i) $\left(1 / W_{H}\right) \cdot(d G / d t)=\left(\mathrm{GIRW}_{\mathrm{t}}\right.$. (ii) $d F / d(G+S+g+s)$ is regarded as $F /(G+S+g+s)$, the ratio of $F$ to $G+S+g+s$ [F-GSgs ratio]. (iii) $\left(1 / W_{N R}\right) \cdot(d g / d t)$ shows the extra grain ingestion rate per unit $W_{N R}$ [gIRW $W_{\mathrm{NK}}$. (iv) $W_{\mathrm{N} /} / W_{i i}$ is regarded as the non-ruminant body mass supplied for human consumption [NRBMHC]. (v) $\left(1 / W_{k}\right) \cdot(d(S+s) / d t)$ shows the straw ingestion rate per unit $W_{k}\left[\mathrm{Ss}_{\mathrm{SRW}}\right]$. (vi) $W_{R} / W_{l l}$ is regarded as the ruminant body mass supplied for human consumption [RBMHC]. Two terms, which are newly given in equation (8) but not shown in equation (7), are explained as follows. (vii) $\left(1 / W_{k}\right) \cdot(d F / d t)$ shows the forage ingestion rate per unit $W_{k}\left[\mathrm{FIRW}_{\mathrm{k}}\right]$. (viii) $d(S+s) / d(G+S+g+s)$ is regarded as $(S+s) /(G+S+$ $g+s)$, the proportion of $S+s$ to $G+S+g+s$ [Ss-GSgs proportion]. The term $d(G+$ g) $/ d(G+S+g+s)$, which is newly given in equation (9) but not shown in equations (7) and (8), is regarded as $(G+g) /(G+S+g+s)$, the proportion of $G+g$ to $G+S+g+s$ [Gg-GSgs proportion].

Equations (7), (8) and (9) show the basic dividing of foods; where ruminants eat forages $\left[\left(1 / W_{R}\right) \cdot(d F / d t)\right]$ and straws from both grain crops for human consumption and extra grain crops $\left[\left(1 / W_{R}\right) \cdot(d(S+s) / d t)\right]$, non-ruminants eat extra grains $\left[\left(1 / W_{N R}\right) \cdot\right.$ $(d g / d t)]$ and humans consume grains $\left[\left(1 / W_{H}\right) \cdot(d G / d t)\right]$ and animal protein from both rurninants $\left[W_{R} / W_{H}\right]$ and non-ruminants $\left[W_{N R} / W_{H}\right]$. This agricultural system also includes other essential factors, namely harvest index of total grain crops $[d(G+g) / d(G+S+g+$ $s)$, or $(G+g) /(G+S+g+s)]$, the production ratio between forages and total grain crops $[d F / d(G+S+g+s)$, or $F /(G+S+g+s)]$, and in addition, the proportion of grain crop production for human consumption to total grain crop production $[d(G+S) / d(G+S+g+$ $s)$, or $(G+S) /(G+S+g+s)]$ that is given by changing the form of equation (5) as follows:

$$
\begin{aligned}
\mathrm{H}_{\mathrm{RNRH}} & =\left(\frac{1}{W_{A}} \cdot \frac{d(G+S+g+s)}{d t}\right) \cdot\left(\frac{W_{A}}{W_{H}}\right) \cdot\left\{\frac{d F}{d(G+S+g+s)}\right\} \\
& =\left\{\frac{1}{W_{A}} \cdot\left(\frac{d(G+S)}{d t}+\frac{d(g+s)}{d t}\right)\right\}\left(\frac{W_{A}}{W_{I I}}\right) \cdot\left\{\frac{d F}{d(G+S+g+s)}\right\}
\end{aligned}
$$




$$
\begin{aligned}
& =\frac{1}{W_{H}}\left[\left(\frac{d(G+S)}{d t}\right) \cdot\left\{\frac{d F}{d(G+S+g+s)}\right\}+\left(\frac{d(g+s)}{d t}\right) \cdot\left\{\frac{d F}{d(G+S+g+s)}\right\}\right] \\
& =\frac{1}{W_{H}}\left[\left(\frac{d F}{d t}\right) \cdot\left\{\frac{d(G+S)}{d(G+S+g+s)}\right\}+\left(\frac{d(g+s)}{d t}\right) \cdot\left\{\frac{d F}{d(G+S+g+s)}\right\}\right],
\end{aligned}
$$

where $d(G+S) / d(G+S+g+s)$ is regarded as $(G+S) /(G+S+g+s)$ [GS-GSgs proportion].

Equation (10) does not include farm animals, but is composed of humans, forages and grain crops. This suggests that the appropriate management of plant production by humans is of great importance to the avoidance of food competition between farm animals and humans (Mahadevan, 1982; Tanaka, 1987).

\section{Suggestions from the present analyses}

The present study shows a simple analytic description of the basic avoidance of food competition among ruminants, non-ruminants and humans. A feature of these analyses is that forages, grain crops, ruminants, non-ruminants and humans are all included in a hypothetic equation and basic relationships among them are derived from this equation, suggesting harmony-like relationships between principles of agriculture and the life of humans. The present analyses suggest a sort of unified viewpoint of the basic avoidance of food competition, but it is much too simple for analyzing today's complicated agriculture system. Nevertheless, we wish to keep in mind the thought of food competition avoidance in order to avoid the food crisis that would occur with the rapid increase in human population, because agriculture must feed more than 6 billion people on the globe now.

\section{REFERENCES}

Blakcly, J. and D. H. Bade 1994 Animal science - yesterday and today -. In "The Science of Animal Husbandry (6th ed.)", Prentice Hall Career \& Technology, Prentice-Hall Inc., New Jersey, pp. 1-38

Cunha, T. J. 1990 Foreword. In "Forage in Ruminant Nutrition", written by D. J. Minson, Academic Press, Inc., Sai Diego, pp. ix-x

Mahadevan, P. 1982 Pastures and animal production. In "Nutritional Limits to Animal Production from Pastures", ed. by J. B. Hacker, CAB International, Farnham Royal, U. K., pp. 1-17

Mc:Donald, P., R. A. Edwards, J. F. D. Greenhalgh and C. A. Morgan 1995 Feeding standards for maintenance and growth. In "Animal Nutrition (5th ed.)", Longman Scientific \& Technical., London, pp. 313-351

Preston, 'T. R. and R. A. leng 1987 Introduction. In "Matching Ruminant Production Systems with Available Resources in the Tropics and Sub-Tropics", Penambul Books, Armidale, Australia, pp. 1-10

Shimojo, M., T. Bungo, M. Tobisa, Y. Imura, N. Koga, S. Tac, M. Yunus, Y. Nakano, I. Goto, M. Furuse and Y. Masuda 1998 A hypothetic equation from which growt are derived as special cases. J. Fac. Agr., Kyushu Univ., 43: 103-109

Shimojo, M., T. Bungo, Y. Imura, M. Tobisa, M. Furuse, Y. Masuda, Y. Yano, Y. Nakano, T. Shao, M. Yunus and 1. Goto 2000 Basic dividing of foods between ruminants and humans when bascd on the production of forages or grain crops, or both - A simple analytic description -. J. Fac. Agr., Kyushu Univ., 44: 287-292

Tanaka, K. 1987 Green Revolution and I. In "Two decades in Green Revolution", ed. by N. Kanazawa, RRIAP (Nihon University), Ryukeishosha Publishing Co., Tokyo, pp. 19-30 (in Japanese) 